\title{
MERAJUT TOLERANSI SOSIAL DI MASA NEW NORMAL
}

\section{Fitriani}

Wabah virus corona kini menjadi realitas sosial yang harus dihadapi masyarakat dunia, khususnya bagi bangsa Indonesia. Tidak dipungkiri bahwa dengan beredarnya kabar virus corona yang telah merambah masuk ke Indonesia, berdampak pada psikis masyarakat yang menjadi lebih over-protektif terhadap lingkungan sekitar. Ketakutan terhadap virus corona telah memberikan pengaruh terhadap sikap sosial masing-masing individu dimana masyarakat sangat mudah menaruh rasa curiga pada orang yang batuk, bersin, atau terlihat pucat disekitar lingkungan. Bahkan tidak sedikit terjadi konflik kekerasan di masyarakat (Mahyuddin et all, 2020).

Ketidakmampuan kita dalam mengelola rasa curiga, takut, sikap over-protektif dalam merespon isu corona ini memiliki potensi untuk merusak hubungan sosial dengan individu lain. Kita saksikan di berbagai tempat, terjadi tindakan-tindakan yang memaksakan kehendak yang menggerus semangat toleransi dan solidaritas sosial di masa pandemi ini.

Sebenarnya, rasa cemas dan ketakutan pada diri masyarakat atas wabah virus corona adalah hal yang manusiawi. Ya, adalah hal lumrah tatkala kita berupaya untuk menghindar demi memutus mata rantai pentebaran virus karena memang kepanikan dan ketakutan tidak dapat ditutup-tutupi (Rasyid, 2020). Namun, jika dilakukan secara tidak bijak, maka yang terjadi adalah disorganisasi dan disfungsi sosial di masyarakat.

Seiring berjalannya waktu istilah 'new normal' mulai mencuat belakangan ini ketika sejumlah negara melonggarkan penguncian setelah kasus virus corona di negara tersebut melandai. Istilah new normal, merujuk pada kondisi kehidupan usai pandemi virus corona dengan berbagai protocol kesehatan yang berlaku.

\section{Pandemi: Dari Disorganisasi ke Disfungsi Sosial Masyarakat}

Disorganisasi sosial adalah gangguan atau keterputusan struktur hubungan sosial dan nilai-nilai yang mengakibatkan hilangnya control sosial atas perilaku individu dan kelompok, pengembangan isolasi dan konflik sosial, dan rasa keterasingan dari arus utama budaya seseorang dalam kondisi atau keadaan anomie (Soekanto \& Sulystyowati, (2013). Disorganisasi masyarakat mengarah pada situasi sosial yang tidak menentu, sehingga dapat berdampak pada tatanan sosial di masyarakat. Wujud nyatanya adalah berupa prasangka dan disikriminasi. Sedangkan, disfungsi sosial adalah kondisi seseorang tidak mampu melaksanakan peran sosial sesuai dengan tugas dan tanggung jawabnya, dan sesuai dengan harapan orang lain. 
Sebagaimana halanya dengan hadirnya virus COVID-19, disfungsi sosial juga terjadi akibat rasa takut atas wabah virus tersebut. Disfungsi sosial membuat seseorang atau kelompok masyarakat tertentu tidak mampu menjalankan fungsi sosialnya. Sejak merebaknya virus corona, sedikit banyak berpengaruh terhadap tatanan hidup masyarakat, bukan hanya itu, kondisi kesehatan fisik, mental serta spiritual masyarakat juga ikut terganggu. Sehingga berpeluang besar menyebabkan pergeseran tatanan nilai sosial dan budaya di dalam masyarakat. Hal yang nyata yang dapat kita lihat belakangan ini yakni memudarnya rasa solidaritas pada diri masingmasing individu. Hal yang menyebabkan kondisi serupa yakni adanya rasa takut berlebih akan penularan virus yang mematikan ini, sehingga tak ayal masyarakat menciptakan sekat di dalam berkehidupan sosialnya. Ancaman seperti ini apabila dibiarkan terus menerus akan merusak tali persaudaraan bahkan memutus silaturahmi antar individu di dalam sebuah kelompok.

Tak hanya itu, tidak sedikit orang yang sengaja memanfaatkan situasi di tengah merebaknya COVID-19 ini dengan cara pembuatan konten-konten yang bernuansa hoax yang menambah kepanikan dan ketakutan masyarakat luas, dalam ilmu sosiologi hal semacam ini dikatakan "patologi sosial" (penyakit sosial) sehingga cenderung melakukan tindakan-tindakan yang berlebihan dalam menyikapi pandemi ini.

Tindakan atau perilaku seperti ini tentu mendapat respon dan kecaman dari seluruh masyarakat karena dianggap tidak memiliki kepekaan dan rasa kemanusiaan serta miskin solidaritas atau dengan kata lain fungsi sosialnya tidak aktif (disfungsi sosial). Pandemi COVID-19 telah berimbas terhadap munculnya patologi sosial yang terwujud dalam tindakan-tindakan penyimpangan sosial (Mahyuddin, 2020). Ini ditandai dengan banyaknya tindakan kekerasan dimana orang melanggar normanorma sosial yang ada. Disamping itu, runtuhnya fungsi pengontrol dari lembaga/institusi sosial yang memberikan keleluasaan dalam bertingkah laku tanpa kendali, tanpa kontrol sehingga norma-norma intitusional kehilangan sama sekali efektifitasnya. Hal ini terjadi tidak lain dan tidak bukan karena kerjadinya disorganisasi/disintegrasi sosial bersebab pandemi COVID-19.

\section{Solidaritas di Era New Normal}

Penguatan nilai solidaritas dan praktik nyata terhadap sesama menjadi hal yang mendesak untuk tetap hadir. Bahkan, rasa solidaritas harus tetap di kumandangkan terlebih lagi dalam kondisi pandemic virus COVID-19 yang hingga kini belum menunjukkan perubahan yang lebih baik.

Memasuki periode yang kerap disebut dengan istilah 'new normal' (kenormalan yang baru), sejatinya akan menuntut banyak perubahan gaya hidup. 
Tentunya hal tersebut akan menimbulkan dampak pada banyak sisi kehidupan yang akhirnya hal demikian sangat mungkin mengikis rasa kemanusiaan yang sebelumnya sangat dijunjung tinggi dalam semua alemen bangsa ini.

Tantangan yang ada dihadapan kali ini jelas bukan sebuah hal yang mudah untuk dilewati, sebab boleh dikata negara ini sejatinya tidak cukup siap menghadapi ancaman pandemik seperti ini. Selain itu kenyataan bahwa vaksin pengobatan yang langsung mampu menyembuhkan manusia dari COVID-19 belum juga ditemukan hingga hari ini. Pilihan mengubah perilaku hidup masyarakat bukanlah hal yang mudah untuk diwujudkan. Tingkat kesulitan ada pada habit masyarakat yang telah lama terbina, menjadikan persoalan yang ada semakin terasa berat.

Kemanusiaan masing-masing individu benar-benar mendapat ujian yang serius, akankah keegoisan masih menjadi primadona dalam era new normal ini? Ataukah masing-masing individu mulai berkenan berfikir perihal kepentingan publik?. Dengan kata lain lebih mengutamakan solidaritas dengan sesama ketimbang mengutamakan hal-hal personal. Apalagi kita sebagai bangsa yang dikenal memang memiliki banyak modal sosial (Mahyuddin, 2019). Modal sosial adalah bagian dari alternatif solusi yang bisa digunakan (Wahyu \& Kustiningsih, 2020).

Dalam mengupayakan kemunculan praktik solidaritas tersebut, nilai-nilai solidaritas yang menjadi pondasi penting mesti menjadi pemahaman bersama terlebih dahulu. Setidaknya dengan pemahaman awal yang kokoh, menghadirkan peluang lebih besar untuk meyakinkan pentingnya merajut semangat kebersamaan ditengah paceklik akibat pandemi. Salah satu nilai fundamental yang menjiwai pemahaman solidaritas adalah membangun "altruisme". Altruisme sendiri merupakan sebuah konsepsi yang bertitik tekan pada perasaan mendasar seorang individu yang ingin berbagi terhadap pihak lain untuk kemanfaatan sosial.

Mencoba membaca kondisi yang ada dan agenda pemerintah melalui kenormalan yang baru dari perspektif di atas, menjadikan kita sadar bahwa agenda kenormalan yang baru bukanlah periode dimana persoalan COVID-19 telah berakhir. Namun, bila berbicara mengenai wujud penghargaan terhadap martabat manusia dalam konteks bersolidaritas di era kenormalan baru, rasanya penting untuk mengingatkan kembali hal mendasar namun mendesak untuk dilakukan, yaitu keharusan mematuhi protokol pencegahan dan penanganan COVID-19. Sebab, dengan tetap mengikuti protokol kesehatan yang telah diagendakan pemerintah tersebut, sejatinya masing-masing individu tidak hanya berupaya menjaga kehidupan yang dimilikinya melainkan juga perpanjangan hidup dari individu lainnya.

Masyarakat Indonesia hari ini memang hidup dalam periode kerentanan yang teramat sangat. Sehingga hanya dengan langkah-langkah bersolidaritas-lah, stabilitas bangsa dalam era kenormalan yang baru masih mungkin terjaga. Dalam konteks ini, masyarakat dari berbagai elemen sosial diharapkan mampu mengatasi masalah yang 
ada di masyarakat serta mampu mengeratkan rasa toleransi meski berbeda suku, ras, dan agama.

Di tengah ancaman pandemi COVID-19 penting untuk selalu membangun kolaborasi yang baik. Ya, di dalam melawan pandemi ini kita harus berjuang bersama-sama. Tidak perduli kita berbeda agama, suku dan lain sebagainya, yang paling penting tetap menjaga solidaritas.

Dengan demikian, memasuki periode yang kerap disebut dengan istilah 'new normal' (kenormalan yang baru), sejatinya akan menuntut banyak perubahan gaya hidup. Tentunya hal tersebut akan menimbulkan dampak ke banyak sisi kehidupan yang akhirnya hal demikian sangat mungkin mengikis rasa kebersamaan yang sebelumnya sangat di junjung tinggi dalam peradaban bangsa ini.

Kerentanan sosial menjadikan posisi ketahanan masyarakat (community resilience) mengalami guncangan (shock) akibat pandemik COVID-19 (Nurkidam et all, 2020). Ketahanan masyarakat berkaitan dengan kemampuan dari masyarakat untuk dapat menggunakan sumber daya yang tersedia (seperti, teknologi, makanan, pekerjaan, dan rasa nyaman makanan) dalam memenuhi kebutuhan dasar dan menjalankan fungsi sosialnya. Dampak kerentanan sosial dapat membuat masyarakat melakukan tiga tindakan yang saling terkait, yaitu tindakan apatis, tindakan irasional, dan tindakan kriminal. Untuk itu, pilihan solidaritas tanpa batas adalah perilaku hidup masyarakat yang perlu ditumbuh kembangkan. Kita tahu bahwa hal ini bukanlah hal yang mudah untuk diwujudkan. Namun, jika kita tidak mengupayakan itu, maka ini akan menjadikan persoalan yang ada semakin terasa berat.

\section{Daftar Pustaka}

Kusnitingsih, W. \& N. (2020). Penguatan Modal Sosial dalam Mitigasi COVID-19. In Tata Kelola Pengangan COVID-19 di Indonesia. Yogyakarta: UGM Press.

Mahyuddin, M. (2019). Modal Sosial dan Integrasi Sosial: Asimilasi dan Akulturasi Budaya Masyarakat Multikultural di Polewali Mandar, Sulawesi Barat. KURIOSITAS: Media Komunikasi Sosial Dan Keagamaan, 12(2), 111-122.

Mahyuddin, M., Ilham, I., \& Rusdi, M. (2020). Horor Coronavirus Deseases dan Konflik Kekerasan Masyarakat: Tinjaun Sosiologis atas Penolakan Jenazah Pasien Covid-19. Jurnal Commercium: Kajian Masyarakat Kontemporer, 3(1).

Nurkidam, A., Bakri, M., Saleh, M., Mustary, E., Budiono, I. N., Rasyid, A., ... Syam, M. T. (2020). Coronalogy: Varian Analisis E Konstruksi Opini. IAIN Parepare Nusantara Press. 